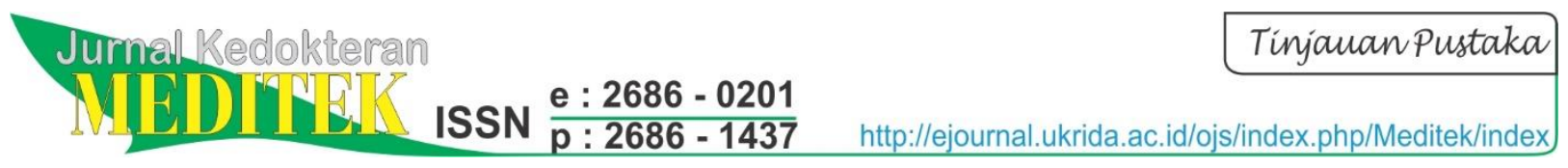

\title{
Diffuse Axonal Injury dan Temuannya
}

\author{
Susilo ${ }^{1}$, Liauw Djai Yen ${ }^{2}$, Rennie Yolanda ${ }^{3}$, Sheilla Dewi ${ }^{3}$, Samantha Shania ${ }^{3}$, Billy \\ Leoprayogo ${ }^{3}$, Geraldo Vivaldi ${ }^{3}$, Janeta Odelia ${ }^{3}$
}

\author{
${ }^{1}$ Departemen Neurologi, Fakultas Kedokteran dan Ilmu Kesehatan, \\ Universitas Kristen Krida Wacana, Jakarta, Indonesia \\ ${ }^{2}$ Departemen Forensik dan Medikolegal, Fakultas Kedokteran dan Ilmu Kesehatan, Universitas Kristen Krida \\ Wacana, Jakarta, Indonesia \\ ${ }^{3}$ Fakultas Kedokteran dan Ilmu Kesehatan, Universitas Katolik Indonesia Atma Jaya, Jakarta, Indonesia \\ Alamat Korespondensi: susilo@ukrida.ac.id
}

\begin{abstract}
Abstrak
Diffuse axonal injury (DAI) adalah cedera mikroskopis yang terjadi di akson pada substansia alba di traktus neuron otak, korpus kalosum, dan batang otak. Biasanya keadaan ini ditandai dengan koma setelah cedera kepala traumatis yang menyebabkan edema dan iskemia pada otak. Keadaan ini sering berujung pada morbiditas maupun mortalitas. Penyebab tersering DAI adalah kecelakaan lalu lintas kendaraan roda dua dengan kecepatan tinggi. Pasien DAI dengan nilai Glasgow Coma Scale (GCS) yang rendah sering dihubungkan dengan faktor prognostik buruk yang berhubungan dengan mortalitas. Diagnosis klinis DAI dapat dibuat berdasarkan visualisasi radiologis, namun diagnosis pasti baru dapat ditegakkan dengan pemeriksaan jaringan post mortem. Pada pemeriksaan makroskopis akan ditemukan gambaran hemoragik pada substansia alba, namun pada autopsi biasanya gambaran tersebut sudah menyusut dan meninggalkan gambaran lesi berwarna cokelat, selanjutnya pada kerusakan yang sudah lama dapat menyebabkan penyusutan volume otak. Ciri kerusakan pada DAI dibedakan menjadi tiga, yaitu kerusakan supratentorial difus pada akson (derajat I), lesi fokal di korpus kalosum (derajat II), dan lesi pada rostral batang otak (derajat III). Pada pemeriksaan mikroskopis tahap awal dapat muncul gambaran "axonal bulb" yang selanjutnya berubah menjadi gambaran aksonal negatif seiring berjalannya waktu.
\end{abstract}

Kata Kunci: cedera aksonal difus, klinis, otopsi

\section{Diffuse Axonal Injury and Its Finding}

\begin{abstract}
Diffuse axonal injury (DAI) is a microscopic injury that affects axons of the substantia alba in the neuron tracts of the brain, corpus callosum, and brainstem. Usually DAI is characterized by coma following a traumatic head injury that causes edema and ischemia of the brain. This situation often causes morbidity and mortality. The most common cause of DAI is high speed traffic accidents. Patients with DAI which has low Glasgow Coma Scale (GCS) are often associated with poor mortality prognosis. Clinical diagnosis of DAI could be made based on radiological findings, but a definite diagnosis can only be confirmed by post mortem tissue examination. On a macroscopic examination, haemorrhagic appearance will be found on the white matter, but at autopsy it has usually shrunk, leaving a brown lesion, meanwhile long-term damage can cause brain volume shrinkage. The characteristics of damage can be divided into three grades; diffuse supratentorial damage to the axons (grade I), focal lesions in the corpus callosum (grade II), and lesions on the rostral brainstem (grade III). Early stages of microscopic examination may show an "axonal bulb" appearance, which subsequently turns into a negative axonal appearance over time.
\end{abstract}

Keywords: clinical findings, diffuse axonal injury, autopsy.

How to Cite :

Susilo, Yen L. D., Yolanda R., Dewi S., Shania S., Leoprayogo B., Vivaldi G., Odelia J. Diffuse Axonal Injury dan Temuannya.

J Kdokt Meditek. 28(1), 72-78. Available from: http://ejournal.ukrida.ac.id/ojs/index.php/Meditek/article/view/2124/version/2088 DOI:

https://doi.org/10.36452/jkdoktmeditek.v28i1.2124 


\section{Pendahuluan}

Diffuse axonal injury (DAI) atau cedera aksonal difus adalah cedera mikroskopis yang terjadi pada akson di traktus neuron otak, korpus kalosum, dan batang otak. Secara klinis, definisi dari cedera aksonal difus adalah keadaan koma yang bertahan selama enam jam atau lebih setelah kejadian cedera otak traumatis yang dapat menyebabkan lesi edema atau iskemia otak. ${ }^{1}$ Adanya DAI dianggap sebagai faktor terpenting dalam penentuan morbiditas dan mortalitas pada korban yang mengalami cedera otak traumatis dan merupakan penyebab tersering dari koma post traumatik, disabilitas, dan keadaan neurovegetatif persisten. $^{2}$

Kondisi DAI terjadi akibat efek dari input mekanis yang terjadi pada otak di dalam rongga tengkorak disaat terjadinya akselerasi dan deselerasi, maka dari itu DAI terjadi akibat kecelakaan lalu lintas, jatuh, dan cedera kepala akibat terbentur benda. ${ }^{3,4}$ Manifestasi klinis yang dapat muncul pada kasus ini antara lain penurunan kesadaran (Glasgow Coma Scale < 8), gegar otak (terutama nyeri kepala), gejala pasca gegar (rasa goyang, mual, muntah, dan lemas), dan bila berat dapat menyebabkan keadaan vegetatif persisten. Juga bisa menyebabkan proses neurodegeneratif jangka panjang. Jadi proses DAI bisa akut, subakut, bahkan kronik bertahun-tahun setelah trauma. ${ }^{5}$ Penyebab paling sering dari DAI adalah kecelakaan lalu lintas dengan kecepatan tinggi. ${ }^{6}$ Riset Kesehatan Dasar tahun 2018 menyatakan bahwa dari seluruh cedera yang menyebabkan terganggunya aktivitas sehari-hari di Indonesia, sebanyak $11,9 \%$ diantaranya disebabkan oleh kasus cedera kepala. ${ }^{7}$ Studi epidemiologi yang dilakukan oleh Vieira et al. (2016), menemukan bahwa dari 78 pasien, 24 orang meninggal dalam kurun waktu 6 bulan setelah kejadian DAI, dengan penyebab DAI tersering adalah kecelakaan lalu lintas pada pengemudi kendaraan bermotor roda dua. $^{2}$

Faktor prognostik yang memengaruhi mortalitas antara lain adalah nilai Glasgow Coma Scale (GCS) awal rendah, respon motorik abnormal, kondisi hipoksia, hipotensi, tanda cedera hipotalamus, durasi kehilangan kesadaran, ukuran pupil awal, kejang, usia, dan jenis kelamin. ${ }^{3}$ Studi epidemiologi oleh Chelly et al. (2011) pada pasien rawat ruang intensif menunjukan angka mortalitas DAI mencapai $42,7 \%$ dengan nilai GCS rendah sebagai salah satu faktor prognostik yang berhubungan dengan mortalitas. ${ }^{8}$

Kejadian DAI dapat menyebabkan malfungsi dan diskoneksi pada interkoneksi neuron, dan hal ini dapat mengganggu banyak area fungsional dari otak. $^{5}$ Kondisi DAI berat yang menyebabkan kematian biasanya adalah DAI pada pasien dengan riwayat hilang kesadaran langsung yang berlanjut dengan koma tanpa interval lucid. Kejadian ini tidak mesti disertai fraktur pada kranial dan pemeriksaan eksternal yang didapatkan hanya menunjukkan cedera minimal. ${ }^{9}$

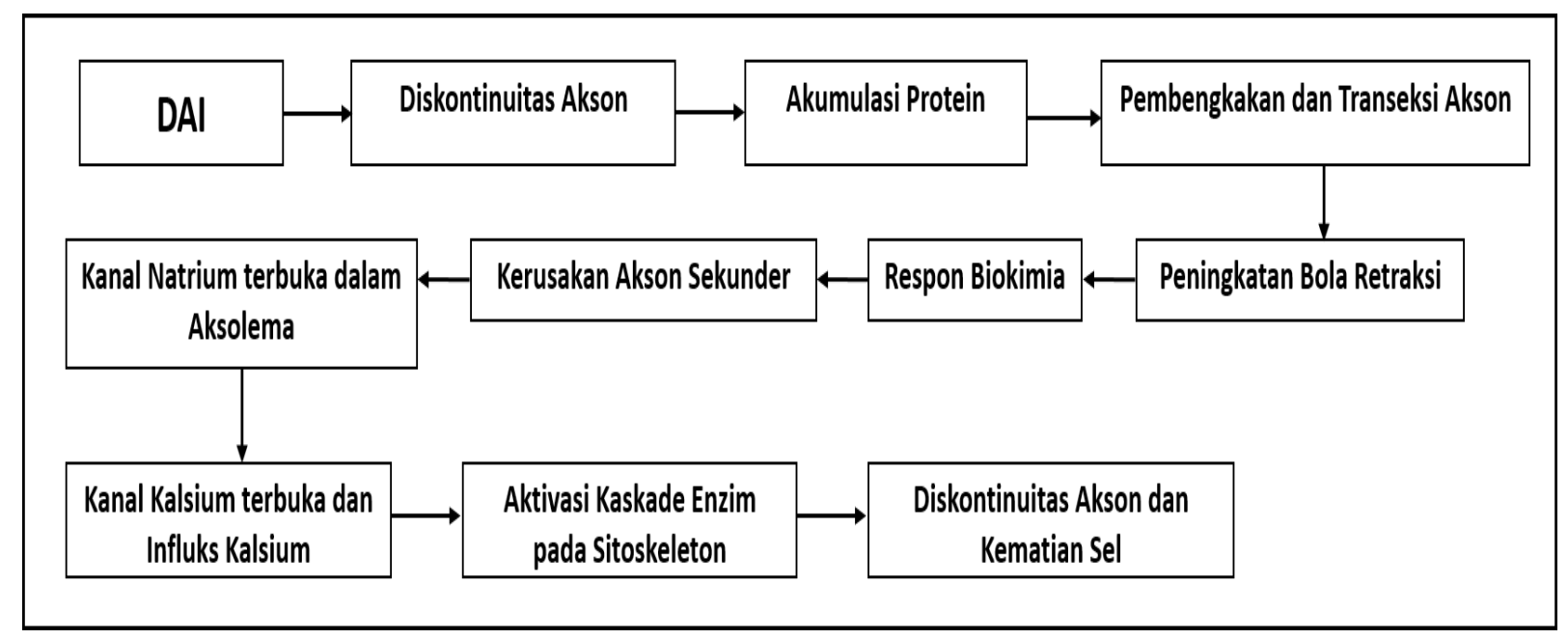

Gambar 1. Mekanisme DAI

Praktik kedokteran forensik berperan dalam menegakan penyebab kematian yang disebabkan oleh DAI. Mekanisme cedera dapat dinilai berdasarkan temuan luka pada scalp, tengkorak, struktur intrakranial, dan jaringan otak. ${ }^{10}$ Pemeriksaan makroskopis pada otak 
pasien adalah cara paling menguntungkan untuk penegakkan diagnosis DAI pada postmortem. $^{9} \quad$ Selanjutnya, pemeriksaan mikroskopis jaringan otak dapat menunjukan adanya edema aksonal dan akumulasi B-APP (Beta-Amyloid Precursor Protein). ${ }^{11}$ Hal ini

\section{Mekanisme DAI}

Diffuse axonal injury (DAI) atau cedera aksonal difus merupakan kerusakan intrakranial dengan karakteristik berupa lesi di dalam substansia alba. Substansia alba terdiri dari beberapa berkas akson bermielin. ${ }^{12}$ Lesi pada substansia alba paling sering memengaruhi lobus frontal dan temporal, namun dapat juga memengaruhi bagian otak lainnya seperti korpus kalosum dan batang otak. ${ }^{13}$ Pada saat terjadi trauma pada otak, langsung terjadi kerusakan dan diskontinuitas akson pada situs impaksi. Kerusakan akson pada otak dapat bersifat ireversibel dan dapat menimbulkan penurunan kesadaran hingga kematian. $^{14}$

Penelitian in vitro oleh Tang-Schomer et al. (2010) menemukan bahwa komponen mikrotubulus pada akson merupakan struktur yang mengalami diskontinuitas bermakna pada saat trauma. ${ }^{15}$ Diskontinuitas mikrotubulus yang berperan sebagai jalur anatomis dalam transpor protein menyebabkan akumulasi protein pada situs diskontinuitas. Hal ini menyebabkan terjadinya pembengkakan pada akson yang mengalami kerusakan. ${ }^{14}$

Pembengkakan akson terbesar terjadi kurang lebih 85 jam setelah trauma. Pasca trauma terjadi peningkatan jumlah bola retraksi selama minggu pertama. Hal ini dikarenakan pada awal trauma terjadi transeksi pada sebagian akson sehingga terbentuk bola retraksi, sebagian akson yang mengalami cedera masih berfungsi untuk beberapa waktu sebelum mengalami penurunan fungsi dan terjadi degenerasi akson. Serangkaian respon biokimia terjadi sehingga menyebabkan kerusakan akson sekunder. Respon biokimia terjadi akibat adanya stress fisik dan regangan yang disebabkan oleh gaya impaksi. Hal tersebut menyebabkan gangguan metabolisme proteolitik dan degradasi sitoskeleton. Selain itu, terjadi pembukaan kanal natrium dalam aksolema menyebabkan gelombang depolarisasi neuronal. Sebagai usaha memungkinkan penentuan mekanisme serta penyebab kematian jenazah yang dicurigai terkait DAI. Tujuan penulisan kajian ini adalah untuk melihat penyebab kematian yang terjadi pada kasus DAI terutama temuan pada pemeriksaan postmortem.

menyeimbangkan influks natrium, kanal kalsium juga terbuka untuk mengeluarkan kalsium dari neuron dan menyebabkan aktivasi kaskade enzim yang bekerja pada sitoskeleton sehingga berujung kepada diskontinuitas akson dan kematian sel. ${ }^{16,17}$

Berbagai penelitian telah menemukan bahwa derajat akselerasi dan rentang waktu terjadinya adalah dua faktor penting yang menyebabkan DAI. ${ }^{1}$ Penyebab DAI antara lain kecelakaan lalu lintas, cedera olahraga, kekerasan, dan jatuh. ${ }^{12}$ Kondisi DAI umumnya terjadi setelah ada akselerasi kepala yang terjadi secara gradual dalam rentang waktu yang cukup panjang. ${ }^{1}$ Pergerakan akselerasi dan deselerasi menyebabkan gaya regang, gaya geser, atau gaya rotasional terhadap substansia alba di otak sehingga menyebabkan cedera aksonal difus. ${ }^{5,18}$ Pergerakan kepala dalam bidang koronal menyebabkan kerusakan akson yang lebih berat dibandingkan pergerakan kepala dalam bidang sagital. Pergerakan kepala dalam bidang sagital menyebabkan kerusakan akson ringan hingga sedang. Hal ini menjelaskan mengapa DAI paling sering disebabkan oleh kecelakaan lalu lintas (KLL) kecepatan tinggi, di mana pada KLL trauma kepala terjadi pada rentang waktu yang lebih lama dibandingkan dengan kasus jatuh atau kekerasan yang menyebabkan deselerasiakselerasi kepala yang berlangsung tiba-tiba dan cepat. ${ }^{1}$ Pada KLL umumnya kepala membentur benda atau permukaan yang menyerap energi sehingga rentang waktu terjadinya akselerasi dan deselerasi menjadi lebih panjang. ${ }^{19}$

Pada praktik klinis, diagnosis DAI dapat dibuat berdasarkan informasi klinis dan gambaran radiografi. Namun, secara umum diagnosis pasti dari DAI ditegakkan berdasarkan pemeriksaan patologis post-mortem jaringan otak. $^{5}$

\section{Temuan Makroskopis pada DAI}

Lesi fokal pada DAI umumnya dapat diidentifikasi secara makroskopis pada pemeriksaan post mortem. Lesi dapat berupa gambaran hemoragik pada substansia alba, 
namun hal tersebut terkadang sulit diidentifikasi pada autopsi karena umumnya gambaran tersebut akan menyusut, sehingga lesi yang dapat ditemukan adalah lesi berwarna cokelat akibat dari persistensi hemosiderin., ${ }^{1,20}$ Pemeriksaan dapat menggunakan Computed Tomography (CT) dan pemeriksaan Magnetic Resonance Imaging (MRI) tradisional, Diffusion-Weighted MRI (DWI) dan Diffusion Tension Imaging (DTI), dan Gradient Echo Pulse Sequence-Susceptibility Weighted Imaging (GRE-SWI). ${ }^{21}$

Makino et al. (2019) melaporkan kasus seorang laki-laki berusia sekitar enam puluh tahun dengan trauma kepala akibat kecelakaan lalu lintas. Pasien meninggal tujuh minggu setelah kecelakaan. Pada pasien dilakukan pemeriksaan Postmortem Computed Tomography (PMCT) dan Postmortem Magnetic Resonance Imaging (PMMR), diikuti dengan pemeriksaan autopsi. Pada pemeriksaan PMMR didapatkan lesi dengan intensitas rendah pada substansia alba parasagital dan korpus kalosum yang menunjukkan adanya cedera aksonal fokal. Gambaran ini sulit ditemukan pada PMCT maupun pemeriksaan makroskopis. ${ }^{22}$ Studi ini memaparkan bahwa tidak ditemukan lesi yang signifikan pada pemeriksaan makroskopik jaringan otak. Penemuan makroskopik yang ditemukan hanya adanya sedikit perubahan warna menjadi kemerahan pada substansia alba bagian dalam di sekitar kornu anterior ventrikel lateral kiri. Pasien dikonfirmasi dengan adanya cedera aksonal pada pemeriksaan histopatologi postmortem. ${ }^{22}$

Studi lainnya oleh Szecsi et al. (2020) melaporkan kasus seorang narapidana berusia tujuh belas tahun yang dipukul berkali-kali pada bagian dagu hingga kehilangan kesadaran dan meninggal. Pada narapidana tersebut dilakukan pemeriksaan autopsi, ditemukan adanya hematoma subdural kronis bilateral dengan ketebalan 2-3 $\mathrm{mm}$ tanpa herniasi serebral atau serebelar. Pada persimpangan antara pons dan myelencephalon, terutama di sekitar ventrikel IV, serta pada nucleus serebelar, tampak beberapa perdarahan petekie. Pada piamater sekitar vermis tampak adanya sedikit perubahan warna menjadi cokelat muda. Selain itu, tampak infark berwarna cokelat muda yang simetris pada nucleus kaudatus, talamus, dan putamen. Pasien dikonfirmasi adanya DAI pada pemeriksaan histopatologis. ${ }^{23}$
Secara umum, gambaran makroskopik DAI berupa lesi hemoragik yang dapat ditemukan pada beberapa lokasi berbeda di otak. DAI memiliki tiga ciri struktural yang berbeda, yaitu kerusakan supratentorial difus pada akson (derajat I), lesi fokal di korpus kalosum (derajat II), dan lesi pada rostral batang otak (derajat III). Letak lesi yang terjadi tersebut dipengaruhi oleh tingkat keparahan dari trauma kepala yang terjadi. DAI derajat III ditemukan lebih sering terjadi pada pasien dengan cedera kepala berat dibandingkan pada pasien dengan cedera kepala yang lebih ringan. ${ }^{20,24}$

Kerusakan difus pada akson hanya dapat diidentifikasi dengan pemeriksaan mikroskopis, sehingga diagnosis DAI hanya dapat ditegakkan dengan pemeriksaan histologis yang memadai. Lesi pada korpus kalosum biasanya terjadi di bagian inferior dan di satu sisi pada bagian midline. Pada kerusakan lanjut, dapat terjadi gangguan pada septum interventrikel dengan perdarahan intraventrikular. Lesi pada rostral batang otak secara khas terlokalisir pada bagian dorsolateral atau bagian yang berdekatan dengan pedunculus serebelar superior. ${ }^{20}$

Intermediary coup contusion juga dikenal sebagai gambaran yang khas pada DAI. Intermediary coup contusion berupa kontusio gliding pada substansia alba di wilayah parasagital lobus frontalis dan kontusio bagian dalam dari basal ganglia dan substansia grisea otak. $^{1}$

Pada pasien dengan DAI yang bertahan selama beberapa bulan, kerusakan yang terjadi pada substansia alba dapat menyebabkan penyusutan volume otak dan pembesaran pada sistem ventrikel. Hal tersebut dapat disalahartikan sebagai gambaran hidrosefalus pasca trauma. $^{20}$

\section{Temuan Mikroskopis pada DAI}

Sejumlah teknik histologis tersedia untuk mengetahui perubahan patologis sekuensial akson pada cedera aksonal difus. Ini terutama ditujukan untuk mempersingkat durasi di mana perubahan aksonal terlihat dan menempatkannya dalam konteks berbagai kondisi traumatik dan non traumatik sehingga dapat membedakan mekanisme penyebabnya. ${ }^{25}$ Pada DAI, awalnya terjadi dilatasi akson yang kemudian dalam 18-24 jam berbentuk bola bulat yang disebut sebagai gambaran bola retraksi. ${ }^{26}$ Pembengkakan aksonal atau bola 
retraksi, mewakili akson yang ditranseksi, merupakan ciri histologis dari cedera aksonal tetapi biasanya tidak terlihat sebelum 24 hingga 36 jam dengan pewarnaan $\mathrm{H} \& \mathrm{E}$ atau dengan pewarnaan myelin seperti Luxol fast blue. ${ }^{11}$ Metode pewarnaan perak dapat digunakan untuk menunjukkan pembengkakan aksonal dalam 12 hingga 18 jam. Cedera pada akson dapat dideteksi lebih awal dalam 6 jam dengan metode imunohistokimia dengan menggunakan immunostaining ubiquitin. Perubahan aksonal reaktif yang persisten dalam bentuk bola retraksi lebih konsisten 24 jam setelah cedera. Imunoreaktivitas lebih kuat jika diamati pada area perifer dibandingkan dengan area sentral.

Biomarkers yang dapat digunakan antara lain $\quad \beta$-APP, Spectrin-II Subunit, Neurofilaments, Tau Protein, Myelin Basic Protein (MBP), cyclooxygenase-2, aquaporin4 , inflammatory reaction factors (seperti IL- $1 \beta$, IL-6, danTNF), dan basic fibroblast growth factor. ${ }^{21}$

Teknik B-APP immunostaining telah berhasil mendemonstrasikan DAI dalam waktu kurang dari dua jam. ${ }^{27,28}$ Adanya $B$-APP biasanya ditemukan pada sel saraf namun tidak terdeteksi secara rutin karena jumlahnya yang kecil. Namun, setelah cedera, B-APP terakumulasi sebagai reaktan fase akut di akson yang membengkak dan dapat divisualisasikan dengan pemeriksaan rutin dan imunohistokimia. Keuntungan utama dari $B$ $A P P$ immunostaining dibandingkan teknik lainnya yaitu $B-A P P$ terakumulasi di dalam akson bahkan sebelum perubahan morfologi akson signifikan lainnya menjadi nyata. ${ }^{26}$ Berdasarkan pola visual cedera akson, teknik $B$ $A P P$ immunostaining dapat membedakan karakteristik perubahan mikroskopis iskemia dari trauma. Pada iskemia akson ditemukan pola bergelombang atau zigzag dengan diferensiasi mendadak area cedera dari area sehat, sementara pada trauma menyebabkan tatanan akson yang tersebar atau berkelompok pada sumbu panjangnya. Kesulitan muncul karena tidak jarang perubahan neuronal traumatik dan iskemia timbul dalam kasus trauma yang sama, sehingga menyebabkan kedua pola tumpang tindih sehingga sulit untuk membedakan kedua entitas ini. ${ }^{29}$ Pada studi kasus oleh Scezi et al. (2020), pada pemeriksaan histologis postmortem menunjukkan peningkatan aktivitas makrofag, proliferasi kapiler, dan astrogliosis reaktif di beberapa bagian kedalaman sulkus, talamus, hipokampus, lesi yang dijelaskan secara makroskopis dari nukleus kaudatus, dan di bagian batang otak yang berhubungan dengan keadaan kronik. Infark daerah anatomis bukan milik arteri serebral utama tertentu. Selain itu, adanya lesi nekrotik berbatas tegas di bagian lateral korpus kalosum dan di kedua sisi segmen dorsolateral pons, selain aktivitas microglia makrofag, juga menunjukkan lampu akson yang menonjol dengan $B$ APPimmunostaining menunjukkan adanya cedera akson yang difus. ${ }^{23}$

Dengan meningkatnya waktu kelangsungan hidup pascacedera, terdapat peningkatan luas dan derajat cedera aksonal di mana perubahan aksonal menjadi lebih jelas secara mikroskopis. Dengan menggunakan silver staining dapat terlihat perubahan yang signifikan pada tampilan saraf yang rusak yang berkembang dari dilatasi sinusoidal pada 2 jam awal menjadi bola retraksi yang tampak besar pada 72 jam. Pembengkakan akson terbesar terjadi kurang lebih 85 jam setelah trauma. Pada pasca trauma terjadi peningkatan jumlah bola retraksi selama minggu pertama. Hal ini dikarenakan pada awal trauma terjadi transeksi pada sebagian akson sehingga terbentuk bola retraksi, sebagian akson yang mengalami cedera masih berfungsi untuk beberapa waktu sebelum mengalami penurunan fungsi dan terjadi degenerasi akson. Namun, dua sampai tiga minggu kemudian terjadi penurunan jumlah bola retraksi dengan dominasi sel mikroglia diikuti oleh astrositosis dan demielinisasi. Setelah periode 2 sampai 3 bulan atau lebih, degenerasi Wallerian bilateral sekunder akan terlihat. Penggunaan neurofilamen immunostaining memungkinkan untuk menentukan durasi DAI mulai dari 30 menit hingga lebih dari 24 jam. Perubahan karakteristik varises atau pembengkakan aksonal dan bola retraksi ditemukan secara maksimal pada daerah substansia alba dalam dan batang otak. Waktu sejak cedera dapat diperkirakan dengan cukup akurat menggunakan $B$-APP imunostaining sejak kurang dari 3 jam hingga lebih dari 6 bulan. ${ }^{28}$ Pada tahap awal cedera aksonal, ditemukan jumlah temuan positif kerusakan aksonal minimal yang berkembang menjadi "axonal bulb" yang sangat positif diikuti dengan kepositifan yang memudar dan akhirnya menjadi reaksi aksonal negatif. ${ }^{2}$

\section{Penutup}


Diffuse axonal injury (DAI) merupakan cedera mikroskopis yang terjadi di akson pada substansia alba di traktus neuron otak, korpus kalosum, dan batang otak yang sering ditandai dengan koma setelah cedera kepala traumatis yang menyebabkan edema dan iskemia pada otak. Penyebab tersering DAI adalah kecelakaan lalu lintas dengan kecepatan tinggi sehingga terjadi peristiwa pergerakan kepala koronal yang dapat menyebabkan DAI yang lebih berat dibandingkan pergerakan kepala sagital. Diagnosis pasti DAI baru dapat ditegakkan dengan pemeriksaan jaringan post mortem, yaitu pemeriksaan makroskopis dan mikroskopis dengan memperhatikan riwayat trauma pasien misalnya seperti riwayat trauma pada beberapa lokasi di kepala karena gambaran DAI pada waktu yang lama dapat disalahartikan sebagai gambaran kelainan lain.

\section{Daftar Pustaka}

1. Mittal P. Diffuse axonal injury: pathological and clinical aspects. Forensic Res Criminol Int J. 2015;1(4): 00026.

2. Vieira RC, Paiva WS, de Oliveira DV, Teixeira MJ, de Andrade AF, de Sousa RM. Diffuse axonal injury: epidemiology, outcome and associated risk factors. Front Neurol. 2016;7:178. doi: 10.3389/fneur.2016.00178

3. Eum SW, Lim DJ, Kim BR, Cho TH, Park JY, Suh JK, et al. Prognostic factors in patients with diffuse axonal injury. Journal of Korean Neurosurgical Society. 1998;27(12):1668-74.

4. Vaidyanathan R, Noor RA, Aravind RM, Shivanand V, Chandrashekar GR. Clinical profile and prognostication of traumatic diffuse axonal injury. J Evid Based Med Healthc. 2020;7(39): 2199-203.

5. Mesfin FB, Gupta N, Hays Shapshak A, Taylor RS. Diffuse axonal injury. In: StatPearls. Treasure Island (FL): StatPearls Publishing; [cited 2021 Jan 11]. Available from: https://www.ncbi.nlm.nih.gov/books /NBK448102/

6. Taylor CA, Bell JM, Breiding MJ, Xu L. Traumatic brain injury-related emergency department visits, hospitalizations, and deaths - United States, 2007 and 2013. MMWR SurveillSumm. 2017 Mar 17;66(9):1-16
7. Badan Penelitian dan Pengembangan Kesehatan Kementerian Kesehatan Republik Indonesia. Laporan Nasional Riskesdas 2018. Jakarta: Lembaga Penerbit Badan Penelitian dan Pengembangan Kesehatan. 2018. [cited 2021 Jan 11]. Available from: https://www.litbang.kemkes.go.id/hasilutama-riskesdas-2018/

8. Chelly H, Chaari A, Daoud E, Dammak, Hssan, Medhioub F, et al. Diffuse axonal injury in patients with head injuries: an epidemiologic and prognosis study of 124 cases. The Journal of Trauma: Injury, Infection, and Critical Care. 2011;71(4): 838-46.

9. Simpson RHW, BersonDS, Shapiro HA. The diagnosis of diffuse axonal injury in routine autopsy practice. Forensic Science International, 1985:27(4), 229-235. doi:10.1016/0379-0738(85)90142-2

10. Davceva N, Janevska V, Ilievski B, Spasevska L, Popeska Z. Dilemmas concerning the diffuse axonal injury as a clinicopathological entity in forensic medical practice. J Forensic Leg Med. 2012;19(7):413-8. doi:10.1016/j.jflm.2012.04.011

11. Hill CS, Coleman MP, Menon DK. Traumatic axonal injury: mechanisms and translational opportunities. Trends in neurosciences. 2016;39(5):311-24

12. Ordookhanian C, Tsai K, Kaloostian SW, Kaloostian PE. Diffuse axonal injury: a devastating pathology. 2018. DOI: 10.5772/intechopen.72828

13. Sindelar B, Bailes JE. Neurosurgical emergencies in sport. Neurologic Clinics. 2017;35(3):451-472.

14. Johnson VE, Stewart W, Smith DH. Axonal pathology in traumatic brain injury. Experimental Neurology. 2013;246:35-43.

15. Tang-Schomer MD, Patel AR, Baas PW, Smith DH. Mechanical breaking of microtubules in axons during dynamic stretch injury underlies delayed elasticity, microtubule disassembly, and axon degeneration. FASEB Journal. 2010;24(5):1401-10.

16. Iwata A, Stys PK, Wolf JA, Chen XH, Taylor AG, Meaney DF, et al. Traumatic axonal injury induces proteolytic cleavage of the voltage-gated sodium channels modulated by tetrodotoxin and protease 
inhibitors. The Journal of Neuroscience. 2004;24(19):4605-4613.

17. Arundine M, Aarts M, Lau A, Tymianski M. Vulnerability of central neurons to secondary insults after in vitro mechanical stretch. The Journal of Neuroscience. 2004:24(37):8106-8123

18. Bray MJC. Examining causes and consequences of mental health disorders in chronic traumatic brain injury. Diss. 2018. [cited 2021 Jan 11]. Available from: https://tspace.library.utoronto.ca/bitstream /1807/91421/3/Bray_Michael_J_201811_ MSc_thesis.pdf

19. Adams JH. Diffuse axonal injury in head injuries caused by a fall. Lancet. 1984:1420-2.

20. Frati A, Cerretani D, Fiaschi AI, Frati P, Gatto V, La Russa R, et al. Diffuse axonal injury and oxidative stress: a comprehensive review. Int $\mathrm{J}$ Mol Sci. 2017;18(12):2600.

21. Junwei M, Kai Z, Zhimin W, Gang C. Progress of research on diffuse axonal injury after traumatic brain injury. Neural Plasticity. 2016; 7 pages.[cited 2021 Jan 11]. Available from: https://www.ncbi.nlm.nih.gov/pmc/articles /PMC5204088/pdf/NP2016-9746313.pdf

22. Makino Y, Arai N, Hoshioka Y, Yoshida M, Kojima M, Horikoshi $\mathrm{T}$, et al. Traumatic axonal injury revealed by postmortem magnetic resonance imaging: a case report. Leg Med (Tokyo). 2019;36:916.

23. Szecsi A, Danics K, Kondracs A, Szollosi Z. Traumatic axonal injury: a case report. The American Journal of Forensic Medicine and Pathology. 2020;41(3):2112.

24. Van Eijck MM, Schoonman GG, van der Naalt J, de Vries J, Roks G. Diffuse axonal injury after traumatic brain injury is a prognostic factor for functional outcome: a systematic review and meta-analysis. Brain Injury. 2018;32(4):395-402.

25. Finnie JW. Forensic pathology of traumatic brain injury. Veterinary Pathology. 2016;53(5):962-78.

26. Le Roux PD, Choudhri H, Andrews BT. Cerebral concussion and diffuse brain injury. 4th ed. New York: McGraw-Hill. 2000.

27. Gleckman AM, Bell MD, Evans RJ, Smith TW. Diffuse axonal injury in infants with nonaccidental craniocerebral trauma: enhanced detection by $\beta$-amyloid precursor protein immunohistochemical staining. Archives of Pathology and Laboratory Medicine. 1999;123(2):146-51.

28. Stone JR, Singleton RH, Povlishock JT. Antibodies to the C-terminus of the $\beta$ amyloid precursor protein (APP): a site specific marker for the detection of traumatic axonal injury. Brain Research. $2000 ; 871(2): 288-302$.

29. Olczak M, Kwiatkowska M, NiderlaBielińska J, Chutorański D, Tarka S, Wierzba-Bobrowicz T. Brain-originated peptides as possible biochemical markers of traumatic brain injury in cerebrospinal fluid post-mortem examination. Folia Neuropathol. 2018;56(2):97-10. 